\title{
On Problems of Career Guidance in Russian School
}

\author{
Andrey V. Luchenkov* \\ Siberian Federal University \\ 79 Svobodny, Krasnoyarsk, 660041, Russia
}

Received 13.04.2015, received in revised form 26.09.2015, accepted 22.10.2015

The article raises questions about creating career guidance system in Russian school. The author has done a research of high school students (of 9 and 11 Year) concerning their professional choice. The author has stated the factors ensure readiness for self-determination of the school graduates.

Keywords: professional orientation, high school student, career choice, career guidance work, selfdetermination.

DOI: 10.17516/1997-1370-2015-8-11-2517-2525.

Research area: pedagogy.

Changes in the social and economic situation in Russia, the transition from post-industrial to an information society, the emergence of market relations, the transition to a society with remarkable entrepreneurial initiative and the change in style of business communication in society contributed to a change in the purpose and nature of work. Labor intensity and tension have increased along with the role of professionalism and responsibility of any specialist. This changes the requirements to the school graduate. Now the school graduate must be prepared to choose their future destiny, to be able to choose the activities, resources, ways to achieve goals, to be able to take decisions, be able to identify their deficiencies and to learn some new things, to be able to plan, acquire new experience and analyze it, turning it into their own life resource. In other words, the school graduate must be active, able to operate efficiently and solve problems effectively. Their activity can be seen in the personal formation as a subject of activity when they reveal their attitude to the activity and create their own "style" (or way) of its realization (Adol'f, Kovalevich).

Professional experience is an important part of human life. It provides a complete selfrealization of personality, revealing all its features; also it has an impact on human emotional state and well-being. Therefore, the study how a man chooses an occupation, further support, and assurance of this process are very important.

The process of choosing a profession implies that young people will have to answer three questions: What can I do? What do I want to get from my professional activities and from my life as a whole? What does the modern world expect from me? How can I be useful to society? What is necessary in order to successfully fit into the

(C) Siberian Federal University. All rights reserved

* Corresponding author E-mail address: aluchenkov@sfu-kras.ru 
existing society? What do I need to be successful in the future? Thus, the process of choosing a profession is to establish ligament "I can - I want - I need to".

The continuous development of the information environment and the accumulation of information resources of the society, along with the computerization of all aspects of life and human activities are placing new demands on the quality of training specialists (A.Toffler, N.F. Rodichev, S.Iu. Rubtsova, P.G. Shchedrovitskii and others). Modern environment puts demands on culture, mobility and education. Changing of periods has affected the change in all spheres of modern life, the economic, political and socio-cultural situations have also changed in the country. This very instability determines the specifics of the psychological problems of a professional choice. On the one hand, in connection with the transition to a market economy, there have emerged some new jobs that "have not put down any roots in the professional culture of our society yet" (Mitina, p. 4). On the other hand, the stereotypes of traditional forms of professionalization ate changing. L.M. Mitina calls this process "withdrawals". Now, it is not enough to be prepared to perform specific functions in the professional life (to be a good specialist). We must be ready to solve all sorts of new problems that arise in the implementation of professional activity, and which have not existed before (that is, to become a professional in the sphere). This means that a person must hold his/her objectivity in a variety of changing situations, to be able to make one's operations, leading to changes and development (Mitina). This is made possible by the presence of the ability of self-development. The values which were relevant the professional world 50 years ago, are now changing. If previously the society supported the value of attachment to the place, a special prowess was "the existence of one and only one employment record", now the ability to be mobile is especially valuable. While earlier labor dynasties (from generation to generation) have been previously valued, now the most important is an ability to retrain in a short time, to acquire the skills from a few professions. And even the education system stopped preparing of "specialists" and is now focused on training workers in particular areas (Bachelors, Masters).

The increased dynamism has affected the world of professions: it has become extremely dynamic and volatile. Every year there appear about 500 new jobs. However, many professions live only 5-15 years, and then they "die" or change beyond recognition(Mitina, p.5). A special feature of the modern world is that monoprofessionalism yields to poliprofessionalism, as noted by many researchers, e.g. S.Ia. Batyshev, A.P. Beliaeva, A.N. Leibovich, L.M. Mitina, A.Ia. Nain, P.G. Shchedrovitskii and others. We see a gap in a previously unambiguous relationship between "profession" and "education". To be successful in the modern world, it is no longer enough to master only one profession. During their professional life people should constantly learn and change.

Thus, we can fix that the modern world of professions, a professional world abandons the professions themselves and comes to the activityoriented positions of people. This means that the system of training young people for successful incorporation into this world needs to change, that is, the system of professional guidance work with pupils must change, too.

Traditionally, a vocational orientation, a career guidance, a professional choice is the system of measures aimed at helping young people to choose a profession (Lat. Professio occupation, French Orientation - setting) (http:// www.edu.ru/abitur/act.15/index.php).

Professional orientation includes:

- professional education as an awareness of the world of professions, schools 
and universities, opportunities for professional careers. For example, educational exhibitions; open days; job fairs; meetings with experts, representatives of various universities and organizations; presentations; workshops on career-oriented subjects; directories; media articles, videos; sites containing information about schools, job description, useful articles, rankings and professions; labor market surveys; online forums; search engines on the Internet; banks vacancies for job seekers and employers;

- professional education as the formation of certain qualities and character traits, such as diligence, efficiency, responsibility, special abilities and aptitudes;

- professional advice on the choice of profession, employment, training opportunities. For example, an interviewjob talk and questionnaires; professional guidance and psychological counseling; career guidance tests and testing systems, evaluating potential of students and their professional qualities (competencies);

- professional development of the individual and the support of professional career, including a change of profession and retraining. For example, trainings and workshops, developing specific competencies required for successful mastering of the profession and to optimization of learning process; business activity games, allowing to try on a variety of professional roles and to reproduce the situation of labor relations and perform the specific tasks in the group; coaching; psycho-technical exercises to develop skills of self-control; computer software simulators; training counselling, forming effective job search and CV writing skills, preparing to selfpresentation and adaptive behavior in the modern labor market.

Career guidance and professional orientation have been the subject of the attention of educators and psychologists since 1970s to the present day. Among the researchers are S.I. Vershinin, A.E. Golomshtok, E.A. Klimov, I.S. Kon, A.K. Markova, N.S. Priazhnikov, N.F. Rodichev, S.L. Rubinstein, M.S. Savina, L.D. Stoliarenko, E.F. Zeer, S.N. Chistiakova, K.A. Abul'khanovaSlavskaia, L.I. Bozhovich, Ia.A. and L.N. Kogan, G.Iu. Liubimova, V.A. Mikheev, P.N. Osipov, V.A. Poliakov, E.N. Proshchitskaia, E. Iu. Priazhnikova, Iu.A. Seleznev, A.A. Bodalev, I.V. Dubrovina, A.V. Mudrik, R.S. Nemov, G.V. Rezapkina, D.I. Fel'dshtein, I.I. Chesnokova and others.

In their authoritative opinion, professional guidance is now understood as a specially organized support of professional and personal self-determination of young people based on their interests, aspirations and abilities. In order to provide the ability to choose a profession among young people there should be formed a habit to choose some option and take responsibility for all the consequences of the choice, regardless of whether they succeeded to foresee them or not.

The existing frameworks that determine education policy say that the professional orientation and psychological support are an integral part of the educational process of any educational organization. For example, the Federal Target Program of Education Development for 2011-2015 proclaims the need to spread the models of successful socialization of students, while teachers should familiarize them with the prospects of employment and conditions of work for selected occupations. The national educational initiative "Our New School" states that the most important qualities of a person in the modern world are creativity, the ability to think creatively, 
the ability to choose a professional way, the willingness to learn throughout the whole life.

But the existing practice, the results, the data of sociological and psychological studies allow us to say that mentioned above tasks set for the school in the field of professional orientation are not solved yet, and the alleged results have not been achieved.

Let us refer to some studies.

According to the laboratory of socioprofessional self-determination of youth based in Institute of Education Development Strategy of the Russian Academy of Education, $50 \%$ of high school students do not correlate their choice of a profession with real opportunities, whereas $46 \%$ are focused on the opinion of parents or their relatives in choosing a profession; $67 \%$ have no idea about the nature of their chosen profession (Blinov, Sergeev).

While doing a sociological study "Value orientations and behavior patterns of young people of the Krasnoyarsk Territory" the researchers studied professional plans and intentions of students of 9 and 11 Year in educational institutions of general education of the Krasnoyarsk Territory. Total the number of surveyed is 5,350 students. $76 \%$ of the respondents when discussing professional plans said they are people who do set goals. $17 \%$ of respondents admitted that they live just for today. However, summing up the results of discussions, the organizers of the study reveal that many young people do not know how to dream, set goals, plan their lives. They found that respondents "do not wish to plan their lives, because they are afraid of disappointment". Many people admit that they do not want to plan their lives, because they are afraid to fail (of 'bummers')" (Tsennostnye orientatsii...)

On this basis, we can assume that high school students do not know how to plan, they do not know how to set goals, formulate the results, choose how to achieve goals, imagine achieving their goals in the form of concrete steps (to lay out), to work with their own resources.

In the same study, the researchers found that there is a difference between the urban and rural students in the definition of criteria for the choice of a profession. At first all the students indicated such a criterion as a high income (53\%). City schoolchildren (49\%) put a criterion of matching of a chosen profession to their interests and abilities in the second place, while village schoolchildren (41\%) put a criterion of demand for the profession in the second place.

These data allow us to suggest that the residence of high students (a village or a city) affects the process of choosing a profession. This influence may be formulated as such: the range of resources for self-determination, ensuring the possibility of choice and professional tries, in addition the "field" of targets depends on the place of residence of high school students, on what opportunities are available. For rural high school students the target to "find a job" is more relevant and more important than for urban high school students.

According to the results of sociological research "Professional plans and intentions of students of 9 and 11 Year in educational institutions of general education of the Krasnoyarsk Territory" from 30 to $40 \%$ of high school students believe that they do not need any help to solve problems of self-determination (Zeer, 2008) (Fig. 1). These findings provoke a question, why do not they need help, why is not it required? And then this means that high school students decide on their professional identity on their own. Or maybe such help, which is provided at schools, is not necessary due to its inefficiency?

But even more interesting for us is the following figure, which shows the respondents' answers to the question of the types of help 


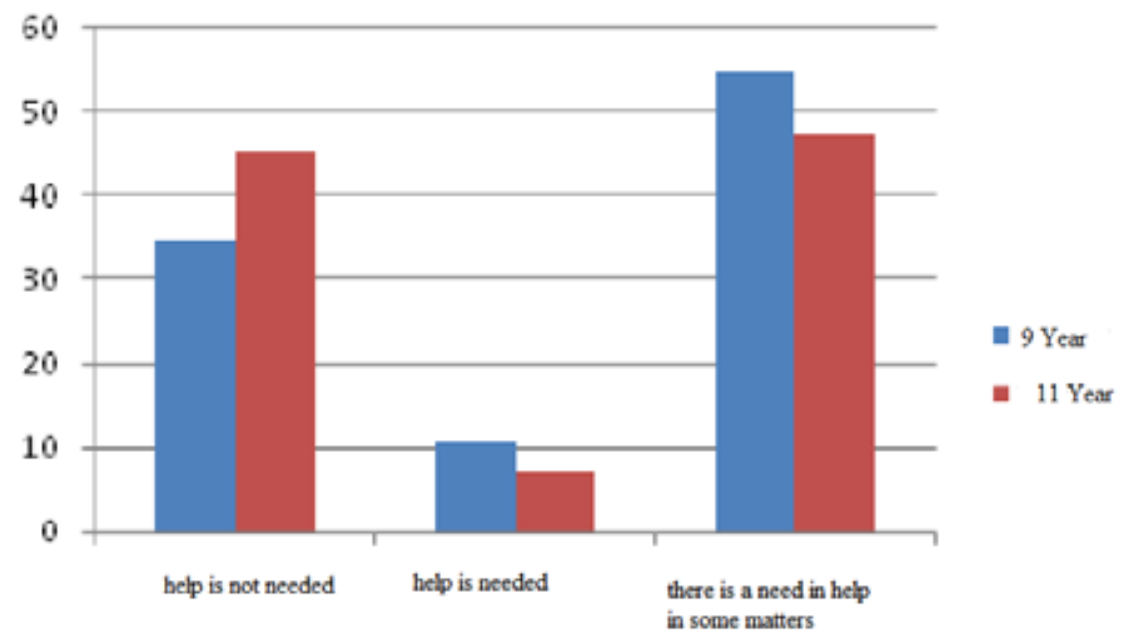

Fig. 1. Need in help to solve the problems of self-determination, $\%$

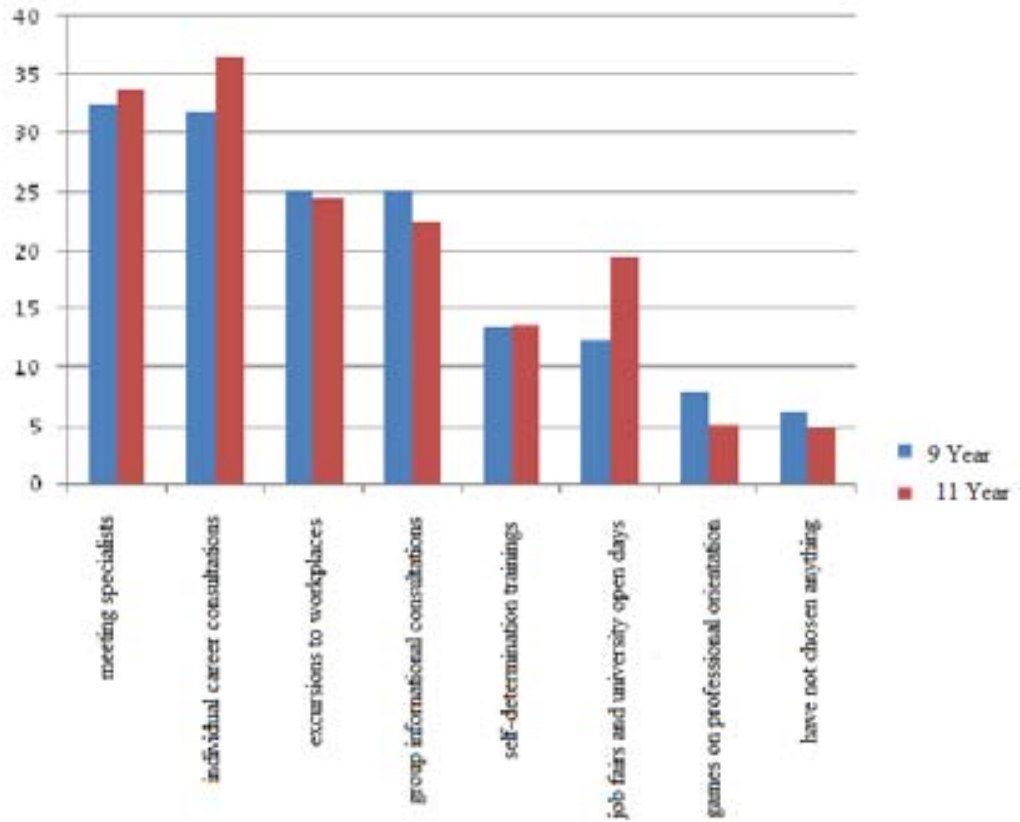

Fig. 2. Types of help in professional self-determination for the students of 9 and 11 Years, $\%$

required for professional self-determination (see Fig. 2).

Statistical analysis of these data using Fisher's exact test showed that there is no statistically significant differences in the demand for certain types of help among students in of 9 and 11 Years in the solution of problems of self-determination.
This is strange, because the situations in 9 and 11 classes are very different. The school graduates face an acute problem of determining at least the next vital step, whether to enter university or not? What university to enter? To move or not to move? To work? To go into the army? and some others. These findings suggest the following: 
neither the $9^{\text {th }}$ nor in the $11^{\text {th }}$ class the children do not question the issues of professional selfdetermination really. This means that the school space, school life function in such a way that the process of professional self-determination is not really started.

In this respect one common and apparently a typical example is one described in the study. Students of 9 Year who plan to continue their studies in the $10^{\text {th }}$ class postpone their decision on the choice of a place of education and a profession to the graduation party in $11^{\text {th }}$ class. This suggests that these students do not have any clear position in relation to their professional choice. And, therefore, the results indicate the absence of conscious learning strategies for the coming period (Zeer, 2008). Thus, we can say that for many students 10 Year turns into a kind of buffer zone, a kind of "waiting room", staying in which may be futile for planning and specifying their professional and educational trajectories.

Next we will present some data from a questionnaire survey conducted among students in 10 and 11 Year, these are students of physics and mathematics classes of SFU school. 132 schoolchildren took part in this survey. Fig. 3 shows the respondents' answers to the question of why they are going to enter the university. In answering this question, respondents could choose more than one answer. Data are presented by specifying the number of respondents (\%) who chose a particular answer. We propose to pay attention to the following data: $50 \%$ of respondents believe that coming to the university ensures a high-paid job in the future; $20 \%$ (i.e. one in five) of the respondents believe that during

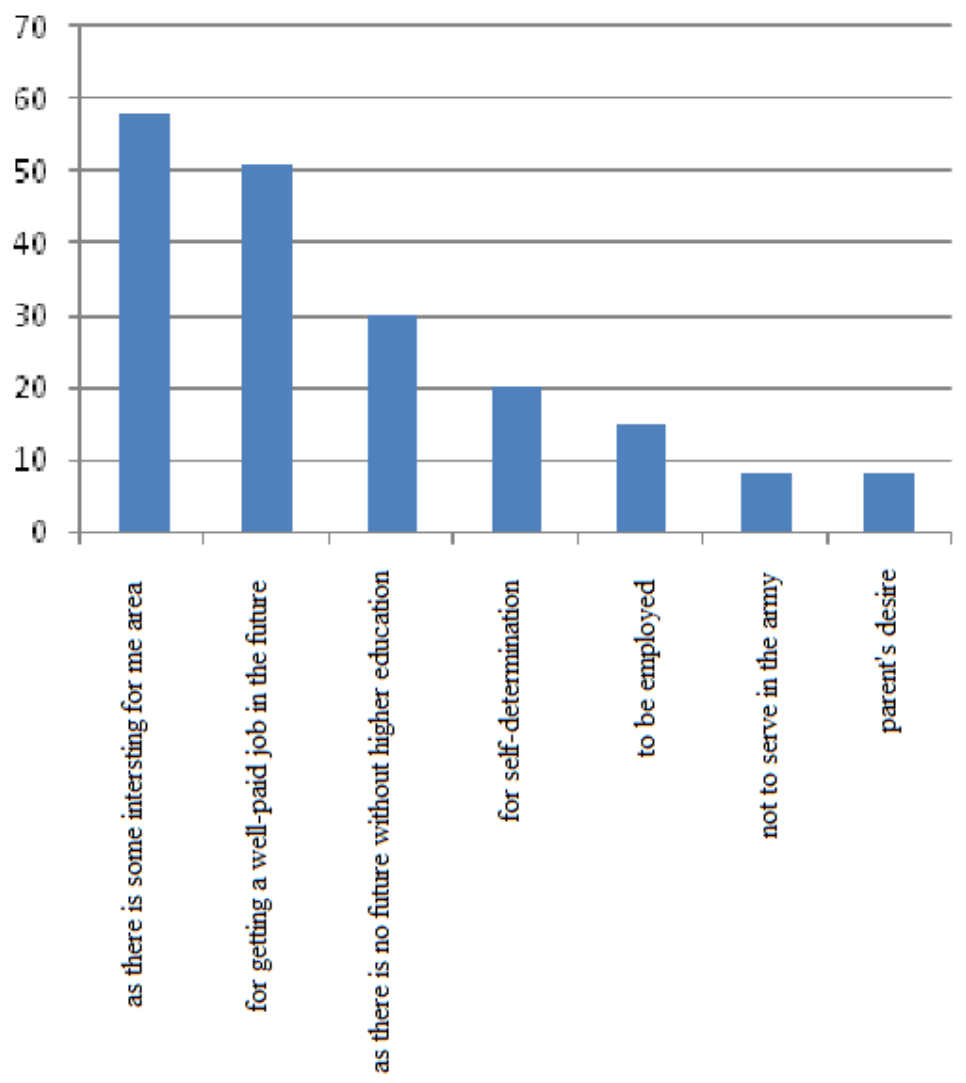

Fig. 3. Why are students going to enter the university?, \% 
the period of study at the university they will be able to make plans about their future with respect to their professional choice.

Fig. 4 shows the respondents' answers to a question of what helps them make decisions about their future. Data are also presented in the number of people ( \%) who selected a particular answer. Attention is drawn to the fact that only $45 \%$ called specialized classes as something that helps in making decisions on their future (and almost all of the respondents were in these specialized classes). In second place there are the parents, $40 \%$ of high school students said that conversations with parents help them decide for themselves. In third place are special Internet sites and universities' sites. About $30 \%$ of the respondents referred to these resources as their assistants. We draw the readers' attention to the fact that educational practices themselves, which are carried out in the educational environment of the school and that should help in making decisions about the future, were named only by $5-10 \%$ of the respondents. These conclusions provoke the emergence of the issue of the quality and adequacy of the proposed forms of work in schools with high school students.

So, despite the fact that the theoretical study of professional orientation and career selfdetermination is high and seems to be examined in detail, the practice shows the ineffectiveness of the methods used in career guidance work.

The purpose of school professional orientation, in our opinion, should be the formation of the capacity for independent and conscious planning, updating and implementing their personal plans. "The challenges facing professional orientation today consist in preparing an individual for professional self-determination, in developing his/her ability for self-learning, self-analysis and in developing his/her skills to search for, find and make (based on their own

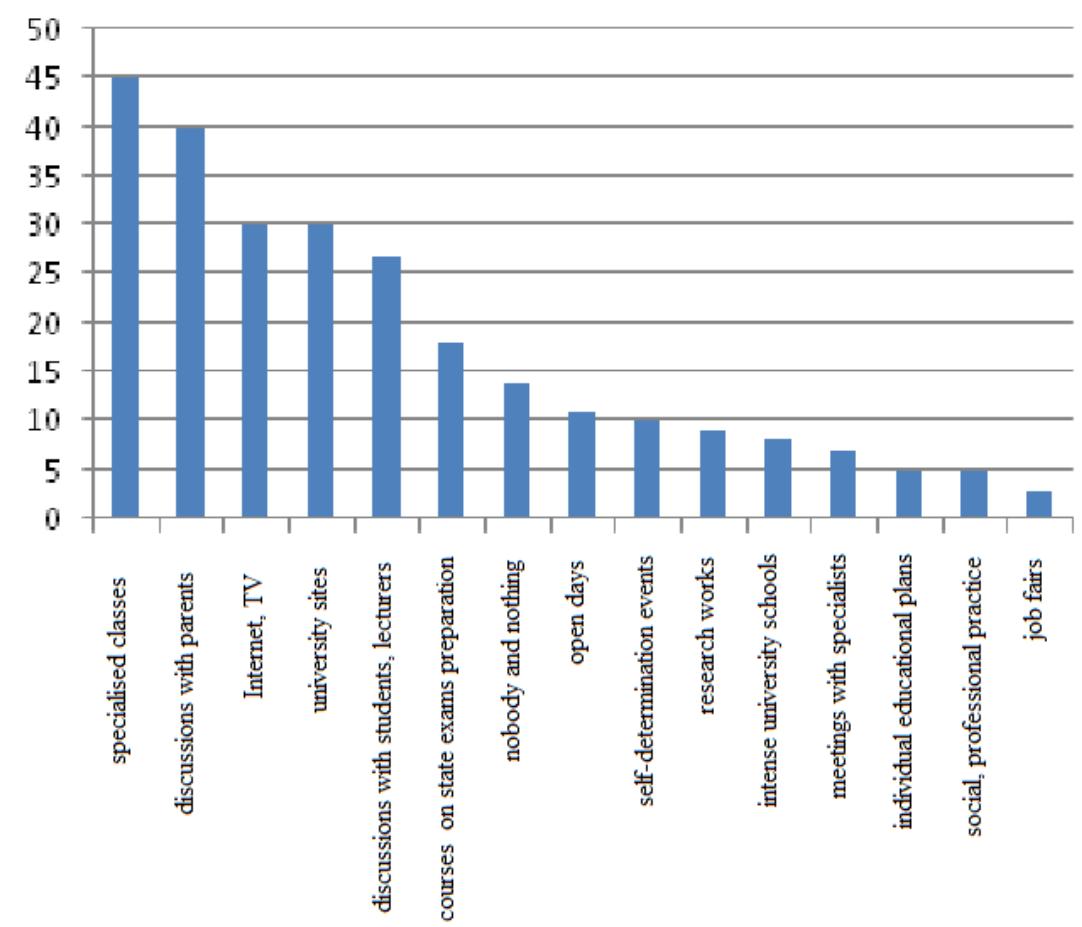

Fig. 4. What helps high school students to make decisions about the future, $\%$ 
choice) adequate decisions" (Adol'f, Kovalevich). So a modern professional orientation is a system of preparation of high school children to a free, conscious and independent choice of profession. This work should take into account the individual characteristics of the person and their needs, on the one hand, and the needs of labor market - on the other.

We emphasize the complexity of the job, as it should be carried out as if in two time layers: the plan of the present (real children today with their troubles and joys), and the plan of the future (children as the future citizens of the country). It becomes relevant to "help a man not to choose a profession, but to find the resources to set their own education and professional formats, as well as training methods for the use of these resources" (Blinov, Sergeev).

Such consideration for the professional orientation suggests discussion of the requirements for professional skills of those who will carry out this work.

To summarize our arguments about career guidance, we can draw some conclusions:
1) The world of professions has changed and the old forms and tasks of professional orientation do not longer work, they are not effective;

2) There is an "event" approach to career counseling, which is not effective, as it cannot create the conditions for self-determination of high school children;

3) Professional orientation is a school operating system, which requires a special design and training and which should be focuses on the processes of self-determination of high school children;

4) Such a system should be based on the idea of the main activity of high school students, i.e. planning;

5) High school students must be accompanied by some assistants in the process of personal, educational, social and professional self-determination;

6) To systematically solve the problem of professional orientation - career selfdetermination it is necessary to put this process in a broader context, to cooperate with other agencies and organizations.

\section{References}

Adol'f, V.A. \& Kovalevich, I.A. (2009). Sovremennye podkhody k ispol'zovaniiu informatsionnoobrazovatel'nogo potentsiala obrazovatel'nogo uchrezhdeniia professional'noi orientatsii uchashchikhsia $v$ kontekste ikh uspeshnoi sotsializatsii [Modern approaches to the use of information and educational potential of educational institutions of professional orientation of students in the context of their successful socialization]. Sovremennye problemy nauki i obrazovaniia [Modern problems of science and education], 4, 7-13, available at: www.science-education.ru/32-1200 (date of reference: 08.09.2015).

Blinov, V.I.\&SergeevI.S.(2012).Kontseptsiiaorganizatsionno-pedagogicheskogosoprovozhdeniia professional'nogo samoopredeleniia obuchaiushchikhsia $v$ usloviiakh nepreryvnosti obrazovaniia [The concept of organizational and pedagogical support of professional self-determination of students in terms of continuous education], available at: http://www.firo.ru/wp-content/uploads/2012/12/ Concept_SPS.pdf (date of reference: 20.08.2015).

Klimov, E.A. Psikhologiia professiional'nogo samoopredelenia [Psychology of professional selfdetermination]. Moscow, Akademiia, 2012, 304 p.

Mitina, L.M. (ed) Psikhologicheskoe soprovozhdenie vybora professii: nauchno-metodicheskoe posobie [Psychological assistance of work: a scientific-methodical textbook]. Moscow, 2003. 
Priazhnikov, N.S. (2003). Shkol'naia proforientatsiia: real'nost' $i$ mechty [School professional orientation: reality and dreams]. Shkol'nyi psikholog [School psychologist], 4.

Priazhnikov, N.S. (2010). Perspektivy razvitiia proforientatsii v sisteme kadrovoi politiki gosudarstva [Prospects for the development of professional orientation in the personnel policy state system]. Problemy proforientatsionnoi raboty $v$ sovremennykh usloviiakh [Problems of professional orientation in modern conditions, materials of all-Russian scientific-practical conference, March 2526, 2010]. Tyumen, Publishing House of TSU, 2010, 6-18.

Priazhnikova, E.Iu., Priazhnikov, N.S. Proforientatsiia: uchebnoe posobie dlia studentov uchrezhdenii vysshego professional'nogo obrazovaniia [Professional orientation: a textbook for students of higher education institutions], $6^{\text {th }}$ ed. Moscow, Akademiia, 2013, $496 \mathrm{p}$.

Rezul'taty sotsiologicheskogo issledovaniia "Professional'nye plany i namereniia uchashchikhsia 9 i 11 classov obrazovatel'nykh uchrezhdenii obshchego obrazovaniia Krasnoiarskogo kraia [The results of sociological research "Professional plans and intentions of students of 9 and 11 Year in educational institutions of general education in the Krasnoyarsk Territory"]. Krasnoyarsk, 2011. available at: http://www.krao.ru/files/fck/File/Morozov/Soc_issled_shk-ki_2011_PC_sokr_variant. docx (date of reference: 20.08.2015).

Zeer, E.F. Psikhologiia professii [Psychology of professions]. Moscow, Academic Project, 2008, $336 \mathrm{p}$.

Tsennostnye orientatsii i povedencheskie stereotipy molodezhi Krasnoiarskogo kraia [Value orientations and behavior patterns of young people of the Krasnoyarsk Territory], Krasnoyarsk, 2011. available at: http://www.krao.ru/files/fck/File/Morozov/socissledovanija_po_molodezhi_Konsalt. docx. (date of reference: 20.08.2015).

\title{
О проблемах профориентационной работы в российской школе
}

\author{
А.В. Лученков \\ Сибирский федеральный университет \\ Россия, 660041, Красноярск, пр. Свободный, 79
}

\footnotetext{
В статье поднимаются вопросы о выстраивании системы профориентационной работьы в российской школе. Приводятся данные исследований старшеклассников на тематику профессионального определения. Выделяются фокусы, обязанные обеспечить готовность к самоопределению выпускников школь.
}

Ключевые слова: профессиональная ориентация, старшеклассник, выбор профессии, профориентационная работа, самоопределение.

Научная специальность: 13.00.00 - педагогические науки. 